\title{
On corporate sustainability integration research: Analysing corporate leaders' experiences and academic learnings from an organisational culture perspective
}

\author{
Kyra Weerts ${ }^{\mathrm{a}}$, Walter Vermeulen ${ }^{\mathrm{b}}$, Sjors Witjes ${ }^{\mathrm{c}, *}$ \\ a Sustainalize, Utrecht, The Netherlands \\ ${ }^{\mathrm{b}}$ Copernicus Institute of Sustainable Development, Utrecht University, The Netherlands \\ ${ }^{\mathrm{c}}$ Institute for Management Research, Radboud University Nijmegen, The Netherlands
}

\section{A R T I C L E I N F O}

\section{Article history:}

Received 11 July 2017

Received in revised form

17 June 2018

Accepted 16 July 2018

Available online 17 July 2018

\section{Keywords:}

Corporate sustainability integration

Change agent

Leadership

Organisational change management

Organisational culture

Values

Mechanisms

\begin{abstract}
A B S T R A C T
Addressing corporate impacts on the sustainability of society entails a dynamic capability and management of organisational change. Although the integration of Corporate Sustainability into the corporate culture involves both the physical and social dynamics of business activities, scientific research has been mostly focusing on interventions in the physical dynamics. This article focuses on interventions in the social dynamics, by analysing literature from environmental sciences on optimising social interventions aiming for the integration of Corporate Sustainability into the corporate culture on the one hand and literature written by successful Corporate Sustainability change agents from industry on the other hand. We use the three perspectives of organisational culture change by Martin (1992) to compare the analysis of scientific and practical literature. By reflecting upon practical and theoretical advances, this research identified practical grounded learnings on Corporate Sustainability integration contributing to both society and science that give input for improvements of research on the integration of Corporate Sustainability. We conclude that where Corporate Sustainability scholars tend to focus on one specific Corporate Sustainability integration approach, the change agents intuitively apply what is best in their specific situations, resulting in a mix of approaches. Consequently, the combative attitude of scholars is not very fruitful. Moreover, all three perspectives on changing organisational culture could be seen in both scientific as well as practical literature as developmental stages of the transformation process. Consequently, including the time dimension in Corporate Sustainability integration research enables a longitudinal analysis to capture social interventions. We, therefore, stress the need for more longitudinal transdisciplinary research approaches aimed at enhanced understanding of how culture at different organisational levels may affect the success of the integration of Corporate Sustainability into the corporate culture.
\end{abstract}

๑) 2018 Elsevier Ltd. All rights reserved.

\section{Introduction}

Companies have increasingly become a focus of attention in the sustainability debate (Cannon, 1994; Elkington, 2002; Hart, 1997), since they are perceived to be responsible for many negative impacts on the environment and on societies (Dunphy et al., 2006). To address corporate impacts on the environment and societies implies intervention in the social and physical dynamics of business

\footnotetext{
* Corresponding author. Heyendaalseweg 141, 6525 AJ, Nijmegen, The Netherlands.

E-mail address: s.witjes@fm.ru.nl (S. Witjes).
}

activities leading to changes in processes and products, revisions of communication strategies, and adaptation of value and knowledge systems (Azapagic and Perdan, 2005a; Marc J. Epstein and Buhovac, 2010; Siebenhüner and Arnold, 2007).

Physical dynamics entail the mechanical and physical processes needed for the production of services and goods and their physical impacts on the ecology and wider environment (Baumgartner, 2009a; Hahn et al., 2015). The social dynamics on the other hand focus on the interactions within the company and its outside social relations with the world (Vermeulen and Witjes, 2016). Past research has mostly addressed the physical dynamics of these interventions (Vermeulen and Witjes, 2016), neglecting the social 
dynamics that arise in the process.

Outside of the academic discourses practitioners have made their own contribution to this debate, by presenting their experiences as Corporate Sustainability (CS) champions in books for the wider business community, which are more or less neglected in the academic discourses. Using practitioners experience on interventions in the social dynamics of business activities responds to the growing need for sustainability researchers to actively connect to the processes they try to understand by using both scientific and practical grounded learnings (Goodman et al., 2017; Willems et al., 2013). Testimonies of successful practitioners can be used as a source for practical grounded learning. Identifying such practical grounded learnings can be achieved by working with and reflecting upon the practical and theoretical interests of society and science simultaneously (Breda et al., 2016) and lead to improvement of the research on the integration of CS.

This paper fills this neglect by analysing the possible guidance available on these issues both for researchers as well as practitioners. This leads to the following two related research questions:

1. To what extent are the propositions by scientists about optimising the social organisational dynamics in CS integration, in line what with similar propositions by successful CS change agents from the industry based on their experiences?

2. What learnings can be drawn from comparing these propositions of scientists and industrial CS change agents for future research on the integration of CS?

The paper contains a threefold literature study (see Fig. 1). Firstly, it analyses general literature defining the most important concepts surrounding social dynamics in organisational systems. These concepts guide the second literature analysis on the influence of corporate culture on the integration of CS and what change mechanisms are proposed. Thirdly, we carry out an extensive literature analysis of strategies described in books written by successful CS change agents from the industry, to see how theory and practice relate and what lessons can be drawn.

\section{Methods}

This research takes as a premise that using knowledge from the practitioners' field is viable for theoretical discourses (Glaser and Strauss, 2008). As such, it makes sense to link practical grounded learnings to the history and developments in organisation theory based on reviews of literature from science and practice.

The first literature review sets the scene and presents a framework on interventions in the organisational culture. By reviewing some of the classic authors in this field, the review gives an overview of different approaches to understand organisational culture change. Going beyond extensive theoretical discourses, we searched for literature which has been applied repeatedly in research. This we found in the work of Joanne Martin (Martin, 1992; Meyerson and Martin, 1987). Her three perspectives on the dynamics of organisational change, which - as we illustrate in section 3 of this paper - can still be applied and integrates various other approaches.

In our second literature review we elaborate on our earlier article on the development of the transformative learning approach (Vermeulen and Witjes, 2016), focusing on scholars proposing different approaches to the integration of CS into organisational culture (which is shown in Appendix 1). This literature analysis represents CS scholars from different academic and geographic backgrounds (European and North American) whose approaches are analysed according the three perspectives on changing organisational culture by Joanne Martin.

In the selection for the third literature review of successful CS change agents from the industry (hereafter referred to as industrial CS change agents) we applied two criteria: First, it should be written by CEO or former CEO, who is generally acknowledged as being a frontrunner in progressively and effectively integrating CS into the organisational culture as was also found in the reviews of the books (on for example Amazon). It is assumed that these

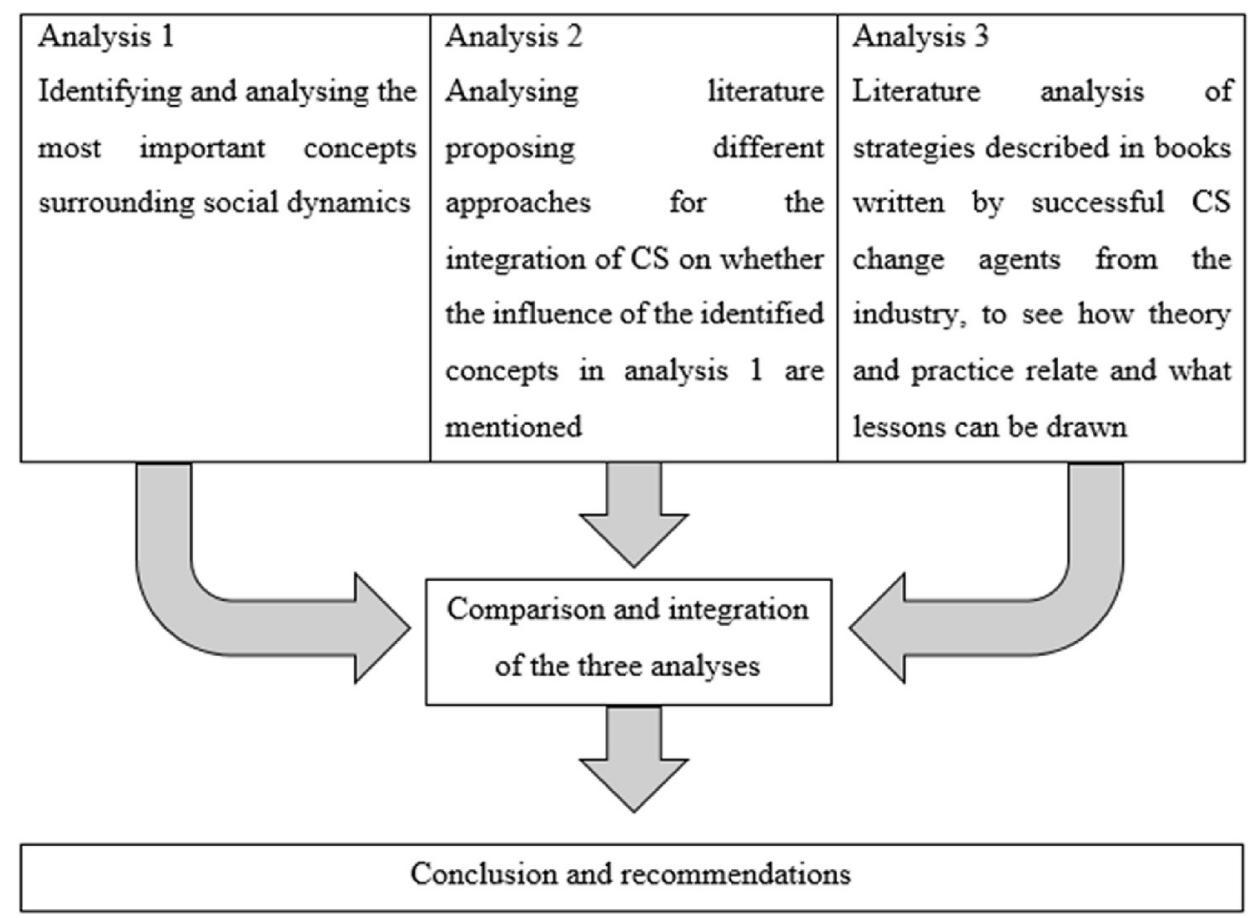

Fig. 1. Structure of the research. 
change agents have the best insight into the lengthy CS integration process. Second, the selected literature should represent as many different sectors as possible to increase the validity and reliability of the results of this third literature review. For the selection, different forums (e.g. Amazon, Google Books) were used, discussing inspiring CS front running CEOs to identify industrial change agents. Those who have written books about their practices are included in the analysis. This first search resulted into the selection of 3 books. Henceforward, an extensive search on various international bookstore websites was carried out using the snowball method for which the titles of the first three selected books were used as a starting point. The various websites recommended literature similar to the six books that were already selected. When meeting the set criteria, the books were selected. This resulted in the list of books presented in Table 1 (as additional material to this article we offer short summaries of these books). As with the literature by scholars on the integration of CS into the organisational culture, the books by industrial change agents were analysed according the three perspectives on changing organisational culture by Joanne Martin from the first literature review.

We acknowledge the small number of literature sources from practice used as data for this research. By limiting ourselves to six well-known cases, there is a built-in bias towards strong leadership. Despite these limitations, using the narratives in these six books proves to be a fruitful source of data to be reflected upon in a combined analysis with academic learnings. For future research we recommend to increase the number of books used.

\subsection{Background of the books}

Most companies described by the authors are either founded in the USA, or in Northern Europe. We see several reasons for this fact. Firstly, most of the companies with the highest environmental impact are in fact founded by people from western societies. Secondly, over the years, environmental regulations have become stricter in most western countries, forcing companies to become greener and search for more sustainable solutions. Thirdly, customers in western countries are often better informed by the media and have higher budgets allowing them to make more responsible choices for sustainably produced products (European Commission, 2015). Fourthly, what can be derived from most of the introductory sections of the books is a high sense of knowledge about the environmental problems we have and will have if we do not change our ways a high sense of guilt and responsibility for the problems that are mainly caused by western societies. The authors aim to show how they are successfully transitioning towards having a much lower impact on the environment and hope to inspire others by describing their journey. The companies discussed are all at least 26 years old and have developed into large, successful businesses.

Another background feature that is important to mention is whether a company integrates a CS vision from the start or whether it made a turn towards sustainability. This is something in which the companies used in the analysis greatly differ. Whereas Patagonia, Herman Miller, Interface and IKEA started without initially caring much for the environment, Seventh Generation and Whole Foods Market started with a CS vision. This can be of influence on the corporate cultural change mechanisms that are proposed by the different successful change agents from the industry.

Finally, the companies discussed in the books are rather similar with regard to cultural backgrounds, age and size but differ highly in their initial visions, some starting with a CS vision while others did not.

\section{Interventions into the organisational culture}

In social sciences, businesses are seen as a phenomenon with a dual nature: as with 'two sides of a coin', the dual nature refers to the simultaneously existing physical dynamics (material flows) and social dynamics in businesses, which are embedded in a larger societal system (Vermeulen and Witjes, 2016). The social dynamics refer to the interactions between individuals in organisations, with their distinct roles, positions, views, values and norms. Organisational change can occur because of these interactions, made possible by intentional interventions in common practices (Bedford, 2015; Burgers et al., 2009). The processes resulting from such intended interventions can be referred to as social intervention dynamics (Vermeulen and Witjes, 2016). The interventions addressed in this article are aimed at the integration of a CS vision and strategy into the organisational culture. Mechanisms leading to interventions in the social dynamics aimed at enhancing the integration of CS are highly determined by the corporate culture including corporate values and norms (as concluded by Cramer (2005) and Linnenluecke and Griffiths (2010)).

\subsection{Corporate culture}

Successful corporate change largely depends on the values, norms and ideology of an organisation's culture (Freeman and Cameron, 1993; Jarnagin and Slocum, 2007). While achieving desired corporate change, corporate culture is encountered as a main hurdle (Doppelt, 2003; Linnenluecke and Griffiths, 2010). Although tools, strategies and techniques may be present in an organisation, failing corporate change occurs because the fundamental corporate culture, including its values and norms, remains the same (Quinn and Cameron, 2006, p. 5). For this paper we use the definition of corporate culture by Schein: "a pattern of shared basic assumptions that the group learned as it solved its problems of external adaptation and internal integration, that has worked well enough to be considered valid and, therefore, to be taught to new members as the correct way to perceive, think, and feel in relation to

Table 1

List of books written by successful CS change agents in which they describe their practices, that is used for the analysis of industrial CS change agents.

\begin{tabular}{|c|c|c|c|c|}
\hline Authors & $\begin{array}{l}\text { Year of } \\
\text { publishing }\end{array}$ & Title & Company & Sector \\
\hline Ruch, D. & 2003 & Leaders \& Followers: Lessons from 45 Years at Herman Miller, Inc. & Herman Miller & Office furniture \\
\hline Anderson, R. & 2010 & Confessions of a radical industrialist & Interface & Carpet tiles \\
\hline $\begin{array}{l}\text { Hollender, J., } \\
\text { Breen, B. }\end{array}$ & 2010 & $\begin{array}{l}\text { The Responsibility Revolution: How the Next Generation of Businesses } \\
\text { Will Win }\end{array}$ & Seventh Generation & Household products \\
\hline Dahlvig, A. & 2011 & $\begin{array}{l}\text { The IKEA Edge, Building Global Growth and Social Good at the World's Most } \\
\text { Iconic Home Store }\end{array}$ & IKEA & Home furnishing products \\
\hline $\begin{array}{c}\text { Chouinard, Y., } \\
\text { Stanley, V. }\end{array}$ & 2012 & The Responsible Company, What we've Learned from Patagonia's First 40 Years & Patagonia & Outdoor clothing and gear \\
\hline $\begin{array}{l}\text { Mackey, J., } \\
\text { Sisodia, R. }\end{array}$ & 2014 & Conscious Capitalism, Liberating the Heroic Spirit of Business & Whole Foods Markets & Supermarket chain \\
\hline
\end{tabular}


those problems" (Schein, 2010, p.9). By distinguishing one group or category of people from another (Hofstede et al., 2004), several levels of culture can be determined that influence each other: the visible and the deeper and less visible level (Kotter and Heskett, 1992).

Schein (2010) identifies three levels of corporate culture: basic assumptions, values and artefacts which refer to the degree of visibility of the cultural phenomenon. The artefacts include the phenomena that everyone sees, hears or feels when encountering a group with an unfamiliar culture. Examples of artefacts are, among others, technology, language, architecture, house style, and observable rituals. While this level is easy to observe, it is difficult to decipher due to one's own interpretations, norms and values (Schein, 2010). Espoused values are justifications based on the learning history of an organisation. If a solution works and if the group shares the perception of that success, a process of cognitive transformation is started (Baumgartner, 2009b). Here, a value will first be transformed to a shared value, after which it is developed into a shared assumption. When this process of social validation is successful, these shared assumptions will change into basic assumptions resulting in the values being taken for granted (Baumgartner, 2009b). This level of organisational culture is the hardest to change as the human mind prefers a state of cognitive stability: questioning a basic assumption can release defensiveness and fear (Schein, 2010). Consequently, understanding values and norms being shared by a group of people in an organisation and how they are established is key when changing a corporate culture.

\subsection{Corporate values}

Corporate values are "evaluative standards relating to work or the work environment by which individuals discern what is "right" or assess the importance of preferences" (Dose, 1997, pp. 227-228). However, corporate values can differ from individual values as values are "an enduring belief that a specific mode of conduct or endstate of existence is personally or socially preferable to an opposite or converse mode of conduct or end-state of existence" (Rokeach, 1973, p. 5 ). With the level of the congruence between corporate and individual values determining an employee's commitment (Finegan, 2000; Posner and Schmidt, 1993), changing a corporate culture implies a form of weighing up preferences.

The distinguished levels of values systems are helpful but need guiding norms to make sure the values are pursued. Different classic definitions of norms stress different elements of what norms aim to attain and how they are established. Broom and Selznick (1963) defined norms as blueprints for behaviour, based on cultural values, by which individuals may seek alternate ways to achieve their goals. A norm "is a statement made by a number of members of a group, not necessarily by all of them, that the members ought to behave in a certain way in certain circumstances" (Homans, 1958, p. 46), whereas Morris (1956) stressed that norms are sanctioned prescriptions. The various available definitions highlight the different levels and gradients in which norms exist, resulting in the coexistence of multiple definitions. Norms guide individuals towards preferred behaviour, self-prescribed by the individual or imposed by a group of people. In a corporate setting, disobedience to corporate norms will lead to sanctions and could eventually lead to resignation (Posner and Schmidt, 1993).

Developing and maintaining a set of corporate norms in the corporate culture could guide the persuasion towards values at individual level that agree with the corporate values (Finegan, 2000; Posner and Schmidt, 1993). Consequently, the resulting employee commitment to a certain corporate strategy can be achieved by mechanisms that change the corporate culture, including its norms, and lead to increased coherence between values at individual and corporate level.

\subsection{Changing corporate culture}

Studies on understanding the mechanisms that change the corporate culture are based on strategic management (Johnson, 1992). Rooted in different social science schools (Allaire and Firsirotu, 1984), various competing approaches on corporate culture can also be identified. Meyerson and Martin (1987) described these competing approaches as paradigms and later brought them together in three perspectives (Martin, 1992), each conceptualising corporate culture differently, resulting in various ideas of how changing a corporate cultural is established. A recurrent concept in the descriptions of the three perspectives is that of ambiguity.

\subsubsection{Perspective 1; integration: harmony and homogeneity}

The first perspective defines culture as an integrating mechanism, which is shared by, or unique to, a specific organisation or group (Clark, 1972; Schein, 2010). Perspective 1 emphasises different kinds and levels of corporate culture of which 'shared' is used as a codebreaker for identifying manifestations of culture. Meyerson and Martin (1987) identify three central characteristics of culture in 'perspective 1 ' which are:

\section{- Consistency across cultural manifestations \\ - Consensus among cultural members \\ - A focus on leaders as culture creators}

According to perspective 1 , corporate culture is a monolith where integrating aspects such as consensus, leader-centeredness and consistency are emphasised. As ambiguity is denied, a picture of corporate clarity and harmony emerges (Meyerson and Martin, 1987). Most perspective 1 research focusses on a relatively superficial manifestation of culture: the espoused values of top management (Waterman and Peters, 1983), communication and decision-making norms (Schall, 1983) or corporate rituals (Trice and Beyer, 1984), which are easier to control. However, some perspective 1 research focus on the deeper manifestations of culture, such as the basic assumptions and understandings which underlie behavioural norms. Both perspective- 1 foci view cultural change as a monolithic process (Meyerson and Martin, 1987). Edgar $\mathrm{H}$. Schein, the most influential perspective-1- researcher, describes seven steps that can be executed by business leaders to facilitate cultural change within organisations (Schein, 1990, p. 117):

1. Leaders may unfreeze the present system by highlighting the threats to the organisation if no change occurs, and, at the same time, encourage the organisation to believe that change is possible and desirable.

2. They may articulate a new direction and a new set of assumptions, thus providing a clear and new role model.

3. Key positions in the organisation may be filled with new incumbents who hold the new assumptions because they are either hybrids, mutants, or brought in from the outside.

4. Leaders systematically may reward the adoption of new directions and punish adherence to the old direction.

5. Organisation members may be seduced or coerced into adopting new behaviours that are more consistent with new assumptions.

\footnotetext{
1 By ambiguity is meant, that which is incomprehensible or unclear and perhaps capable of having several meanings (Kleinedler, 2005). It is an internal state, like the feeling of confusion.
} 
6. Visible scandals may be created to discredit sacred cows, to explode myths that preserve dysfunctional traditions, and destroy symbolically the artefacts associated with them.

7. Leaders may create new emotionally charged rituals and develop new symbols and artefacts around the new assumptions to be embraced, using the embedding mechanisms described earlier".

Schein's (1990) change model assigns a lot of influence to leaders and change agents. When they manage to simultaneously create ambiguity and psychological safety, this induces motivation to change (Meyerson and Martin, 1987). It is however essential that there is a good balance between the level of ambiguity and psychological safety. If either is missing there will be no incentive to change (Schein, 1990). Jönsson and Lundin (1976) describe corporate change as cycles of enthusiasm and discouragement focussed on key ideas about meaning and necessity of corporate behavioural structures. Shared enthusiasm for a myth enables action, whereas internal conflicts decay this enthusiasm (Jönsson and Lundin, 1976). Internal conflicts decay the enthusiasm surrounding an existing myth, until a new ghost myth arises, causing ambiguity. Employees need clarity to guide their activities and therefore it needs to be decided to replace the old myth with the new. This process forms a recurring cycle (Martin, 1992).

In sum, perspective 1 researchers, such as Schein (1990) and Jönsson and Lundin (1976), but also other scientists who developed similar models of cultural change (e.g. Brunsson, 1982; Pettigrew, 1985), offer a sequential portrayal of corporate collapse and renaissance of the monolithic culture (Martin, 1992) in cycles that start with (1) clarity, followed by the (2) introduction of ambiguity after which (3) a new clarity is defined.

\subsubsection{Perspective 2; differentiation: separation and conflict}

Whereas in perspective 1 integration and homogeneity are emphasised, perspective 2 is characterised by differentiation and diversity, when describing corporate culture (Chuang et al., 2004; Martin, 1992). Perspective 2 researchers focus on inconsistencies, non-leader centred sources of culture and a lack of consensus. Where 'perspective 1' has a rather closed-system view on culture, perspective 2 has an open perspective, framing culture as being formed by influences from inside and outside the organisation (Chuang et al., 2004). In opposition to perspective 1, according to perspective 2 organisations do not have a monolithic culture, but instead they see culture as an entity composed of a collection of values and manifestations which might be contradictory (Martin, 1992). However, agreement on the basic values is important Once this is established, diversity on other value levels is not problematic, but will nurture successful corporate cultural change (Martin and Siehl, 1983; Van Maanen and Barley, 1984).

Perspective 2 researchers argue that due to subcultural differentiation, corporate cultural changes are more localised and incremental. This emphasises environmental or external catalysts for change, that have a localised impact on the company's functioning. These changes are often loosely coupled and are generally not planned nor controlled by the management. Chuang et al. (2004) argue that diversity and different subcultures can be managed through a corporate culture. Corporate cultures are locally defined, and change occurs continuously through the diverse composition of a group. The success rate of cultural change through diversity depends on the congruence of seven dimensions identified by Chuang et al. (2004):

1. Innovativeness: this includes values of being open to new opportunities, being willing to take risks and to experiment, being innovative and less rule oriented.
2. Stability: this dimension values stability, rules and security.

3. Attention to detail: here being precise and analytical are valued.

4. Respect for people: this dimension emphasises fairness, respect and tolerance.

5. Team orientation: being people oriented, team oriented and collaborative are emphasised in this dimension.

6. Outcome orientation: values of being achievement-, action-, and results-oriented are important.

7. Aggressiveness: this includes the values of being highly competitive with little attention to social responsibilities.

Although some dimensions tend to contradict, this is not problematic as not all dimensions need to be adhered to. However, once a dimension is valued by a company, it is important that this opinion is shared by its employees (Chuang et al., 2004). Successful corporate cultural change is channelled through agreement on these dimensions and is initiated through diversity on other values. It can therefore be concluded that where perspective 1 denies ambiguity, in perspective 2, ambiguity is channelled (Meyerson and Martin, 1987).

\subsubsection{Perspective 3; fragmentation: multiplicity and flux}

Perspective 3 differs from the first two perspectives primarily in its treatment of ambiguity. Where perspective 1 and 2 respectively deny and channel ambiguity, perspective 3 accepts and cultivates ambiguity. Perspective 3 considers consistency and consensus as abstract illusions which are created by management for the purpose of control. Perspective 3 researchers see or even look for confusion or paradoxes (Meyerson and Martin, 1987). They argue that there can be many advantages to cultivating ambiguity in corporate goals, such as increased creativity and flexibility (Mohr, 1983). Where perspective 2 focuses on environmental sources of subcultural change, perspective 3 emphasises an individual's capacity to adjust to environmental fluctuations, which includes patterns of attention and interpretation. This is best described by Keesing (1981) describing culture "does not itself adapt to environments but is the means through which individuals adapt to their environment ... culture develops, elaborates, or stagnates in a process of individual cultural innovation" (Keesing, 1981, p. 167).

Perspective 3 researchers argue that ambiguity can be managed and created through the creative use of symbols (Eisenberg, 1984) and implicit corporate values in myths and sagas. Equivocal expression of corporate values allows for multiple interpretations, while promoting a sense of unity. This is also commonly referred to as strategic ambiguity (Eisenberg, 1984). Strategic ambiguity facilitates corporate change, as it allows for different interpretations of corporate goals and metaphors. Corporate culture changes when its members change the way they interpret the symbols and corporate myths.

Furthermore, as psychological safety is provided by an increased acceptance of ambiguity, expectations and evaluation criteria remain unclear. This makes individuals less at risk when experimenting, which gives them a heightened sense of autonomy that creates safety. Accepting ambiguity creates more freedom for creativity and experimentation. It can be argued that perspective 3 draws attention to those changes, which are by definition uncontrollable, that underlie innovation processes (Martin, 1992).

In short, guidelines for cultivating ambiguity may encompass the following:

1. Use equivocal corporate value statements.

2. Create spaces for discourse within your company.

3. Enable individuals to adjust and experiment.

4. Create a sense of autonomy amongst employees. 


\section{Set vague evaluation criteria.}

The three perspectives present different and on various points competing suggestions on how to frame organisational change. We illustrate the three perspectives in Fig. 2 with the key elements as described above, and indicate conflicting approaches with the reddotted arrows and comparable approaches with the green arrows. This threefold distinction can still be found in more recent literature, with a certain dominance of the perspective 1 styles (see e.g. Beer et al., 1990; Kotter, 2007), but also approaches addressing organisational change as a multi-authored negotiation (Buchanan and Dawson, 2007; Thomas et al., 2011) or as discourse (Heracleous and Barrett, 2001).

For the main purpose of this article, we use the three perspectives to understand to what extent the propositions by scientists about optimising the social organisational dynamics in CS integration are in line what with similar propositions by successful CS change agents from the industry based on their experiences and what learnings can be drawn from comparing these propositions of scientists and industrial CS change agents. Such research has not been undertaken yet, to our knowledge.

\section{Analysis of scientific literature on CS integration into the organisational culture}

CS scholars from different academic and geographic backgrounds have been proposing approaches for the integration of CS into the organisational culture. In our earlier article on the development of the transformative learning approach (Vermeulen and Witjes, 2016), we analyse scholars proposing different approaches to the integration of CS into organisational culture. In this article we analyse the work of these scholars according to the three perspectives on changing organisational culture by Joanne Martin. The value system on transcending corporate values and ambition levels for integrating CS as defined by Van Marrewijk and Werre (2003) will be used to assign the different values and motivations described by the CS scholars to a corresponding value level as identified by Van Marrewijk and Werre (2003). From the values and motivations, the guiding norms are derived. This will help to designate the approaches of the CS scholars to the three perspectives on changing organisational culture by Joanne Martin as identified in section three.

\subsection{Analysing corporate culture in the scientific articles}

In Table 2 the results of the literature analysis are shown on whether and how the CS scholars mention the influence of corporate culture in relation to the integration of CS. Here, a difference is made between literature in which the influence of corporate culture is extensively discussed $(+)$ and literature where this is only briefly mentioned $(-) .50 \%$ of the papers reviewed discussed corporate culture. Generally, we can conclude that in almost all articles the influence of corporate culture on the integration of CS is stressed; however various wordings are used to describe this. Therefore, it can be questioned whether they are aiming to paraphrase the same.

\subsection{Analysing corporate values in the scientific articles}

As almost all articles stress the importance of corporate culture, it is relevant to deepen this analysis. The integration of CS asks for more than just compliance with the corporate vision and has been proven to be most successful when employees' values align with the corporate vision and values (Johnson, 1992). Van Marrewijk and Werre (2003) developed a more extensive value system identifying six transcending corporate values and ambition levels for integrating CS:

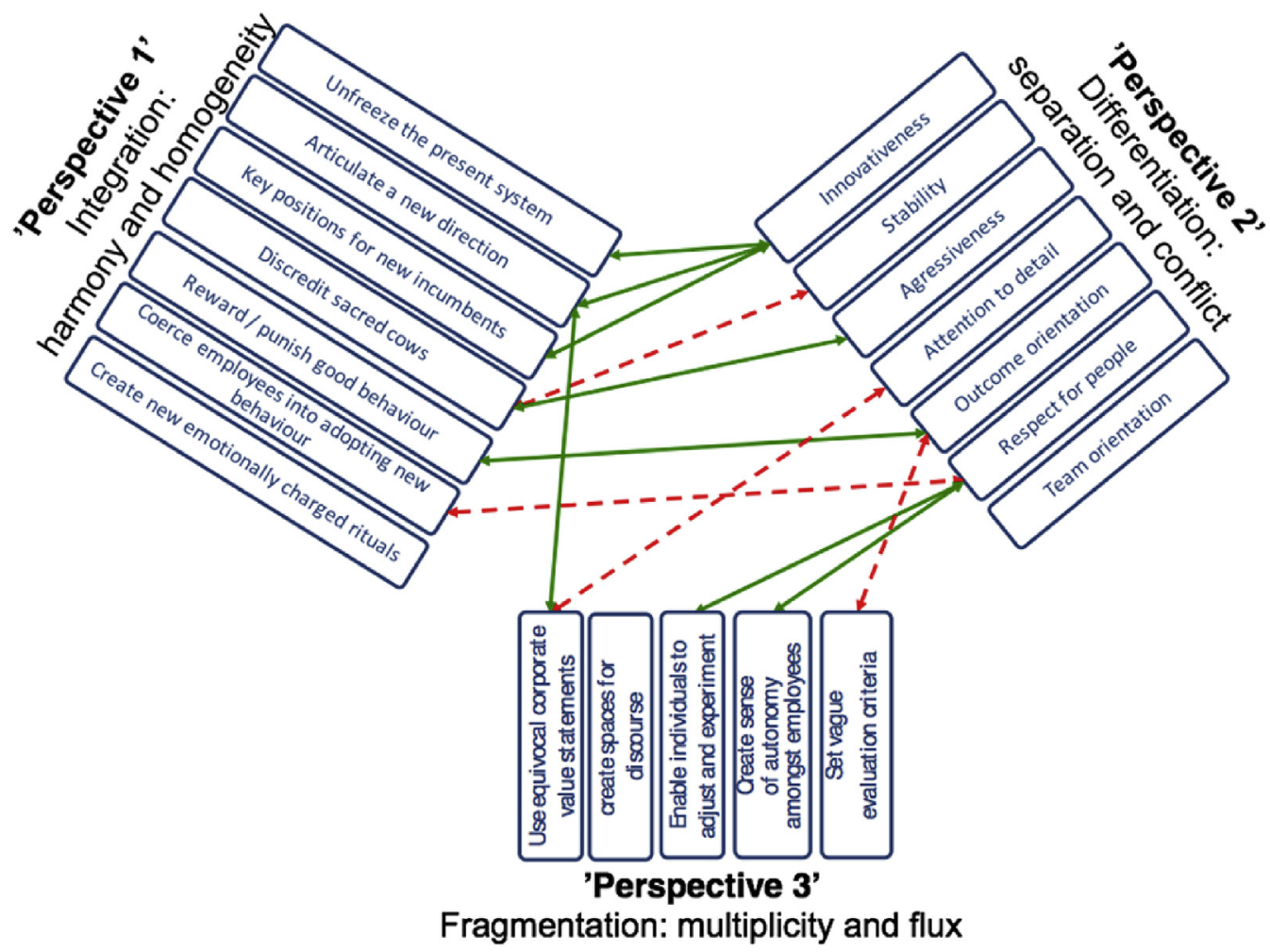

Fig. 2. Key differences and commonalities of three perspectives of organisational change (based on (Meyerson and Martin, 1987) and (Martin, 1992)). 
Table 2

Results of the analysis on whether and how the most important scientific authors in the field of CS mention the influence of corporate culture in relation to CS.

\begin{tabular}{|c|c|}
\hline Articles & Description of influence of corporate culture \\
\hline Van Marrewijk and Werre, 2003; Van Marrewijk, 2004 & $\begin{array}{l}\text { ‘value systems in organisations' (2003, p.109) (+) ‘supporting culture and personal } \\
\text { commitment’ }(2004, \text { p.136) ‘cultural dimension' }(2004, \text { p.137) }(+)\end{array}$ \\
\hline Searcy, 2011; Ahi and Searcy, 2014 & 'internal infrastructure' (2014, p.124) (-) 'internal procedures' (2011, p.45) (-) \\
\hline Asif et al., 2013 & 'social side of the organisation' (p.16) 'CSR culture' (p.16) (-) \\
\hline Hahn et al., 2015; Hahn and Scheermesser, 2006 & $\begin{array}{l}\text { 'CS as a multilevel construct that positions the firm within a set of relationships with } \\
\text { factors from individual, social-cultural ... levels' }(2015, \text { p.7) }(-) \text { 'social management' } \\
(2006, \text { p.153) (-) }\end{array}$ \\
\hline Baumgartner, 2009b, 2014 & $\begin{array}{l}\text { 'organisational culture' }(2014, \text { p.260) 'management philosophy' }(2014, \mathrm{p} .261)(+) \\
\text { 'corporate culture' }(2009, \mathrm{p} .105) \text { 'internal culture' }(2009, \mathrm{p} .110)(+)\end{array}$ \\
\hline Schaltegger et al., 2013 & 'social management' (p.220) (-) \\
\hline Azapagic, 2003; Azapagic and Perdan, 2005; Azapagic, 2003 & 'socially responsible culture' $(2003, \mathrm{p} .308)(+)$ \\
\hline Epstein and Widener, 2010; Epstein and Buhovac, 2010 & $\begin{array}{l}\text { 'informal systems' (2010, p.306) 'internal context' }(2010, \mathrm{p} .308)(+) \text { 'organisational } \\
\text { culture' (2001, p.588) ‘corporate culture' }(2001, \mathrm{p} .593)(+)\end{array}$ \\
\hline Cramer, 2005; Van der Heijden et al., 2010 & 'culture of the company' (2005, p.588) (-) \\
\hline Linnenluecke and Griffiths, 2010; Linnenluecke et al., 2009 & $\begin{array}{l}\text { 'organisational culture' }(2010, \text { p. } 357)(+) \\
\text { 'organisational culture' and 'social realities' }(2009, \text { p. 433) }(+)\end{array}$ \\
\hline Dunphy et al., 2006 & 'business culture' (2006, p. 10) (+) \\
\hline Lozano, 2008, 2013 & $\begin{array}{l}\text { 'collaborative measures' }(2008, \text { p. 502) }(-) \\
\text { 'the human element' }(2013, \text { p. } 279)(+)\end{array}$ \\
\hline
\end{tabular}

(+) Influence of corporate culture extensively discussed in the article.

(-) Corporate culture is only mentioned briefly.

1. Pre-CS: at this level there is basically no ambition for CS. Some steps that might be labelled as CS are taken when forced from the outside. Close monitoring is required.

2. Compliance-driven CS: here, CS consists of providing welfare to society within the set limits of regulations imposed by authorities. Also, organisations might be responsive to charity and stewardship considerations. CS is seen as a duty and obligation.

3. Profit-driven CS: at this level, the integration of social, ecological and ethical aspects starts to play a more increasing role in business operations and decision-making processes. CS is promoted when profitable.

4. Caring CS: here CS consists of balancing economic, social and ecological concerns. CS initiatives go beyond complying with regulations and profit considerations and include care for the planet, social responsibility and human potential.

5. Synergistic CS: here a synergistic, win-together approach with all relevant stakeholders is aimed at with functional solutions, creating economic, social and ecological value. Sustainability important and inevitable for progress.

6. Holistic CS: at this level, CS is integrated and embedded in every aspect of the organisation. The aim is to contribute to the quality and continuation of life now and in the future. CS is the only alternative.

We will use the transcending corporate value system as defined by Van Marrewijk and Werre (2003) as a guiding reference to further analyse the literature by CS scholars. A brief overview of the results of this analysis is shown in Appendix 2. Generally, it can be concluded that most of the value levels identified by Van Marrewijk and Werre (2003) are also discussed in the different articles as can be seen in the following analysis of the literature by CS scholars using the transcending corporate value system:

The descriptions of the 'pre-CS level' from the CS scholars differ somewhat from the transcending corporate value system. According to the transcending corporate value system, within the 'pre-CS level' a company does not or not yet have any ambition for integrating CS: CS is only integrated when imposed from outside. In the literature by CS scholars, it is argued that it is integrated as a riskmitigating strategy.

The descriptions of the 'compliance-driven CS level' are very similar; both defining it as being mostly characterised by governmental and social pressure where compliance helps to increase legitimacy and build a good reputation. At this level, companies are more responsive to charity and stewardship considerations than at the first level.

The descriptions of the 'profit driven-value level' are also very similar. They both identify that reputation still plays an important role; however, the focus has shifted towards creating sustainable competitive advantages through eco-efficiency and innovation. CS is solely integrated if considered to be profitable.

With regard to the 'care-driven CS level' there is a subtle difference: where the transcending corporate value system focusses more on balancing economic, social and ecological concerns resulting in better care for the planet, the literature of CS scholars stresses the feeling of ethical responsibility towards the natural and social environment. In the latter case, 'care' is more related to norms and values of the individual employee.

The descriptions of the 'synergistic-driven CS level' also closely match, as both stress the importance of including all relevant stakeholders. The literature of CS scholars adds the necessity of a long-term perspective.

Lastly, the 'holistically-driven CS level' is described as a necessity of CS to be fully integrated and embedded in every aspect of the organisation. The literature of CS scholars describes it in a rather practical way by stressing life cycle thinking and closed loop products, rather than focusing on the values behind it to contribute to the quality of life and continuation of life now and in the future as is described in the transcending corporate value system.

\subsection{Analysing changing corporate culture in the scientific articles}

The analysis of the literature of CS scholars using the transcending corporate value system was used to create the overview of how literature by the CS scholars address the three perspectives by Joanne Martin on changing organisational culture, as can be found in Appendix 3. Per CS scholar, this results in the following analyses:

In his article Van Marrewijk (2004) Marcel van Marrewijk stresses the importance of good leadership, placing him firstly in perspective 1 . He explains that cultural change does not happen solely from a top-down approach by stating that "you can bring a horse to the water, but you can't make it drink" (Van Marrewijk, 2004, p.139). He later states that cultural differentiation should be valued, celebrated and channelled, so that it becomes an advantage. This approach is in line with perspective 2. Van Marrewijk and Werre 
(2003) argue for a perspective 3 approach, stressing that a company should "re-align their value systems and all their business institutions (such as mission, vision, policy deployment, decision-making, reporting, corporate affairs, etcetera) to ... new circumstances" (Van Marrewijk and Werre, 2003, p. 108). These changing societal circumstances are seen as an incentive to move to the next value system.

Muhammad Asif, is his article Asif et al. (2013) develops an integrated management systems approach to CSR in which they plead for a 'top-down' and 'bottom-up' approach. At first sight one would think that this aims to describe a perspective 1 and perspective 2 approach. However, with bottom-up they mean considering outside, local influences and feedback, arguing "Given that CSR is contextual and dynamic in nature from the perspective of stakeholders, their requirements, time, geographical location and business type, continuous learning is needed to deal with increasingly complex and many-a-times interrelated issues, in interaction with the diverse range of stakeholders" (Asif et al., 2013) which places them in perspective 3 .

In his article Hahn et al. (2017), Tobias Hahn critically examines six articles on fundamental aspects of the sustainability debate. In one of these, written by Friedrich and Wüstenhagen (2017) it is argued that managers who are faced with decisive sustainability events, experience the phases of denial, anger, bargaining, depression and acceptance that people go through subsequently when facing an irretrievable or impending loss. This implies a topdown approach, requiring strong leadership which is in line with the perspective 1 approach. Slawinski et al. (2017), another article examined by Hahn et al. (2015) argues that the pressure on managers to develop short term results causes managers to shy away from uncertainty. This is used to explain why organisations do not take effective action to address climate change. It denies the broad existence of a perspective 3 approach. Hahn and Scheermesser argue that "Managerial decision-making fundamentally depends on the perceptions and images of decision-makers". "And this holds also true in the context of sustainability issues" (Hahn and Scheermesser, 2006, p. 152). Although Hahn and Scheermesser emphasise that "manager's perceptions of the world constitute the knowledge base from which decisions are made" (Hahn and Scheermesser, 2006, p. 152 ), it is not specified who these decision-makers are.

The argumentation of Rupert Baumgartner in Baumgartner (2014) can be placed in the perspective 1 and perspective 2 approach as he argues "the willingness of the top management level to integrate a corporate sustainability strategy is an essential prerequisite ..." (Baumgartner, 2014; p. 267) underlying the importance the integration approach of perspective 1 . Besides he states that "in business practice it is often the case that new initiatives are launched on lower management levels. If lower management levels can prove that these initiatives have been successful, usually top management will also accept and support these initiatives" (Baumgartner, 2014; p. 267) which underlines the important of differentiation approach of perspectives 2 .

Adisa Azapagic develops in Azapagic and Perdan (2005) an integrated sustainability decision-support framework. However, they do not expand on who these so-called 'decision-makers' are, placing their approach in both perspective 1 and perspective 2 . In another article, Azapagic (2003) argues "The CEO, management board and senior management team have a critical role to play in setting up and integrating the Corporate Sustainability Management System, by demonstrating leadership and strategic commitment to sustainability" (Azapagic, 2003, p. 305). It stresses a solely top-down approach, placing her approach in perspective 1 .

Marc Epstein can be placed in perspective 1 as they argue "The role of committed leadership can never be overstated. Management commitment to sustainability as a core value, and management recognition that sustainability can create financial value for the organisation through enhanced revenues and/or lower costs are critically important" (Epstein and Buhovac, 2010, p. 307). They furthermore state that "The local and global external contexts significantly affect the choices a corporation makes regarding the formulation and integration of sustainability actions" (Marc J. Epstein and Buhovac, 2010, p.308) placing them also in perspective 3 . Epstein and Widener (2010) in their article present a framework to help guide managers identifying and measuring the key performance drivers, focusing on local change, channelling ambiguity, placing their approach in perspective 2 .

Jacqueline Cramer argues in Cramer (2005) that CEOs and top management are responsible for the creation of a vision and mission with respect to making efforts in the field of CSR, placing her in perspective 1. Together with Angela van der Heijden, Cramer stresses in Van Der Heijden et al. (2010) the importance of strong leadership to determine the balance between people, planet and profit. They however furthermore describe how ambiguity "can interrupt an ongoing flow and stimulate people to initiate "novel" action" (Van Der Heijden et al., 2010; p. 1789). Corporate cultural change happens when these so called 'shocks' take place, placing their approach in perspective 3.

In sum, we can conclude from these analyses of CS scholars using the three perspectives on changing organisational culture that there is a trend in corporate cultural change mechanisms that fit the perspective 1 and perspective 2 description of Martin (1992) because most articles do not clearly define the 'initiator' of change, leaving space for individual interpretation However, all articles stress the importance of top-down support.

\section{Analysis of literature of industrial CS change agents}

We now take a closer look at how industrial CS change agents describe the integration of CS into the organisational culture. We focus on similarities and differences between the books from the industrial CS change agents. Brief summaries of the six books can be found in the additional material provided with this article.

This fifth section starts with an analysis of the backgrounds of the different companies described in the books. Second, their framing of corporate cultures including central values and guiding norms will be analysed. Then we compare their strategies to establish corporate cultural change, with the different scientific perspectives as described in section two.

\subsection{Analysing corporate culture in the books}

In Table 3 shows how the industrial CS change agents describe the influence of CS integration on the corporate culture. Here, a difference is made between literature in which the influence on the corporate culture is extensively discussed $(+)$ and literature where this is only briefly mentioned ( - ). Whereas Ray Anderson of Interface briefly mentions the influence of the integration of CS on the corporate culture, the other authors extensively discuss this issue: a good corporate culture is often measured with a company's performance and the average length of employment (Whole Foods Market \& IKEA), it is facilitated through a strong leader determining the most important values (Herman Miller, Interface \& Whole Foods Market).

\subsection{Analysing corporate values in the books}

In Table 4, the books are analysed by the different value levels as identified by Van Marrewijk and Werre (2003).

The values can be mostly derived from the responsibilities and goals described in the various books. Mackey and Sisodia (Whole 
Table 3

Results of the analysis on whether and how the most important industrial CS change agents describe the influence of corporate culture.

\begin{tabular}{|c|c|}
\hline Books & Description of influence of corporate culture \\
\hline The Responsible company by Chouinard and Stanley, 2012, Patagonia & $\begin{array}{l}\text { "At Patagonia we've noticed changes in cohesion when we move different departments to } \\
\text { different floors and buildings. Adjacency and proximity matter: to have our environmental } \\
\text { team next door to the CEO engendered a certain dynamic; the CEO at the time became an } \\
\text { environmental enthusiast." (p.75) (+) }\end{array}$ \\
\hline Leaders and Followers by Ruch, 2003, Herman Miller & $\begin{array}{l}\text { "The new social contract between employers and employees will indeed take many forms } \\
\text { depending on the core values and beliefs of the organisation and the needs of individuals." } \\
(\mathrm{p} .93)(+)\end{array}$ \\
\hline Conscious Capitalism by Mackey et al., 2014, Whole Foods Market & $\begin{array}{l}\text { "Culture can account for up to half of the difference in operating profit between two } \\
\text { organisations in the same business. Shaping a culture is one of a leader's most important } \\
\text { jobs" (p.217) (+) }\end{array}$ \\
\hline Confessions of a Radical Industrialist by Anderson, 2010, Interface & "When the people lead, the leaders will follow." (p.204) (-) \\
\hline The IKEA Edge by Dahlvig, 2011, IKEA & $\begin{array}{l}\text { "The company tries to eliminate all status symbols and create a trustful relationship between } \\
\text { employees and managers. This makes a difference to many workers and entices them to stay } \\
\text { with Ikea even when other firms offer them more money." (p.19) (+) }\end{array}$ \\
\hline $\begin{array}{l}\text { The Responsibility Revolution by Hollender et al., 2010, Seventh } \\
\text { Generation }\end{array}$ & $\begin{array}{l}\text { "Today, good companies work like a community. Talented people, animated by the } \\
\text { community's sense of purpose, provide the brainpower for generating breakthrough ideas } \\
\text { and the firepower for getting them out into the world." (p.19) }(+)\end{array}$ \\
\hline
\end{tabular}

(+) Influence of corporate culture extensively discussed in the article.

$(-)$ Corporate culture is only mentioned briefly.

Table 4

CS value levels that are emphasised by the industrial CS change agents, classified by using the different value levels identified by Van Marrewijk and Werre (2003).

\begin{tabular}{|c|c|c|c|c|c|c|}
\hline & $\begin{array}{l}\text { Pre- } \\
\text { CS }\end{array}$ & $\begin{array}{l}\text { Compliance } \\
\text { driven CS }\end{array}$ & $\begin{array}{l}\text { Profit } \\
\text { driven CS }\end{array}$ & $\begin{array}{l}\text { Care } \\
\text { driven CS }\end{array}$ & $\begin{array}{l}\text { Synergistic } \\
\text { driven CS }\end{array}$ & $\begin{array}{l}\text { Holistically } \\
\text { driven CS }\end{array}$ \\
\hline The Responsible company by Chouinard and Stanley, 2012, Patagonia & & & & $(\mathrm{x})(\mathrm{p} .38)$ & & $\mathrm{X}(\mathrm{p} .61-63)$ \\
\hline Leaders and Followers by Ruch, 2003, Herman Miller & & & & $(\mathrm{x})(\mathrm{p} .21-22)$ & & $X(p .97-100)$ \\
\hline Conscious Capitalism by Mackey et al., 2014, Whole Foods Market & & & & $(\mathrm{x})(\mathrm{p} .8)$ & & $X(p .9)$ \\
\hline Confessions of a Radical Industrialist by Anderson, 2010, Interface & & & & & & $X(\mathrm{x})(\mathrm{p} .41-43)$ \\
\hline The IKEA Edge by Dahlvig, 2011, IKEA & & & $(\mathrm{x})(\mathrm{p} .20-21)$ & & & $\mathrm{X}(\mathrm{p} .45)$ \\
\hline The Responsibility Revolution by Hollender et al., 2010, Seventh Generation & & & & & $(\mathrm{x})(\mathrm{p} .178)$ & $X(p .163)$ \\
\hline
\end{tabular}

$\mathrm{X}=$ The value level that the company described in the book has reached.

$(\mathrm{x})=$ The most important value stressed in the book.

Foods Market), for example, define values and purpose as a passion "for helping people to eat well, improve the quality of their lives, and increase their lifespan. Our purpose is to teach people what they put into their bodies makes a difference, not only to their health and to that of the people who supply the food but also to the health of the planet as a whole" (Mackey et al., 2014, p.48). While Anders Dahlvig (IKEA) exemplifies the importance of different value levels and norms as he argues "Not only is maintaining environmental standards a cost ..., but in fact environmental work can contribute to increased profitability, more motivated workers, and a long term strengthened position in a market. (Dahlvig, 2011, p.35).

Stressing both the value of profitability and responsibility to actively contribute to a better society, Ruch (Herman Miller) stresses the care-driven value by formulating the duty of a responsible businessperson, stating: "The greater good of society is not some fuzzy notion for somebody else to worry about, but a duty of every responsible businessperson" (Ruch, 2003, p.2). In addition, Anderson (Interface) opts for a change in perspective, dismissing 'waste' from our vocabulary arguing: "We do not own the earth. We are part of it. And there is no place called 'away' for throwing things, either. Thinking there was had put us on a collision course with two of nature's iron laws of thermodynamics that we have been slow to realise: Nothing goes away or ceases to exist, it just disperses; and everything is connected - that what we do to the earth and we also do to ourselves" (Anderson, 2010, p.11). In general, the descriptions of all CS change agents are diverse but also rather similar, describing the company's purpose, defining a broad corporate responsibility resulting in strong, self-imposed norms and values.

In sum, the companies described in the books do not necessarily pass through all the phases of the transcending corporate value system by Van Marrewijk and Werre (2003). In contrary, CS scholars describe the different value levels as a linear transition model. Furthermore, the CS change agents from practice emphasising the 'care driven' value level mostly derive their core values from religious principles describing the importance of stewardship. Also, Ray Anderson of Interface stresses the positive influence of religious values when integrating CS.

\subsection{Analysing changing corporate culture in the books}

In Table 5, the books are analysed by using the three scientific perspectives on corporate cultural change by Joanne Martin as defined in section two. The different value levels as identified by Van Marrewijk and Werre (2003).

Yvon Chouinard and Vincent Stanley (Patagonia) stress that "most fundamental cultural changes start at the margins and move toward the centre" (Chouinard et al., 2011, p.71), making them to be placed in perspective 2. Cultural change in Patagonia according to Chouinard and Stanley is decentral and locally initiated. However, they do acknowledge that no formal company initiative can be successful "without top-down support or at least the absence of interference" (Chouinard et al., 2011, p.71). Chouinard et al. (2011) stress three of the seven dimensions identified by Chuang et al. (2004):

- Respect for people, emphasising fairness, respect and tolerance (Chouinard et al., 2011, p.23).

- Team orientation, emphasising broad collaboration and team work within a company (Chouinard et al., 2011, p. 53).

- Outcome orientation, emphasising clear goals and measured results (Chouinard et al., 2011, p.54).

Strong leaders set basic values as: respect for people, team 
Table 5

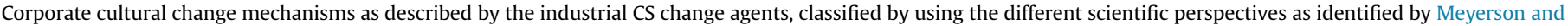
Martin (1987). Page numbers of where the main reasoning can be found in the book are put behind for transparency.

\begin{tabular}{|c|c|c|c|}
\hline & 'Perspective 1'; Integration & 'Perspective 2'; Differentiation & 'Perspective 3'; Ambiguity \\
\hline The Responsible company by Chouinard and Stanley, 2012 & $\mathrm{X}(\mathrm{p} .71)$ & $\mathrm{X}(\mathrm{p} .70-75)$ & \\
\hline Leaders and Followers by Ruch, 2003 & $X(p .47-51)$ & & \\
\hline Conscious Capitalism by Mackey et al., 2014 & $X(\mathrm{p} .181,217)$ & & $X($ p. 220-229) \\
\hline Confessions of a Radical Industrialist by Anderson, 2010 & $X(p .212)$ & & \\
\hline The IKEA Edge by Dahlvig, 2011 & $X(p .36)$ & & \\
\hline The Responsibility Revolution by Hollender et al., 2010 & & & $X(p .56-57)$ \\
\hline
\end{tabular}

orientation, outcome orientation and aggressiveness, in the case of Patagonia. They grant their employees trust to differ on other values, allowing decentral and local corporate cultural change to happen. It can, therefore, be argued that the CS integration approach Chouinard et al. (2011) describe fit perspective 1 and 2.

Dick Ruch (Herman Miller) describes the responsibilities leaders and followers have towards each other and towards society. These are strongly related to the seven steps that can be executed by business leaders, as defined by perspective 1 researcher Schein (1990) to facilitate corporate cultural change. Leadership may unfreeze the present system with the formulation of a new vision, purpose and strategy. Their first responsibility is to convince others of this new approach and then guide the change through the appointment of the right people for the right job, and lead by example. Ruch argues that "If the leadership doesn't point us in the right direction, we're all in trouble" (Ruch, 2003, p.40). It can, therefore, be argued that the CS integration approach Ruch (2003) describes fit perspective 1 .

The description of John Mackey and Rajendra Sisodia of the Whole Foods' approach is less easy to assign to a specific corporate culture perspective. In some parts of the book, leaders are appointed as most influential change agents, arguing that "leaders have an inherent systemic sensitivity that enables them to understand both how a group of people will behave as a system and how to change the system in order to change its behaviour" (Mackey et al., 2014, p.181). Further on they again state that "shaping a culture is one of a leader's most important jobs" (Mackey et al., 2014, p.217). However, the authors also stress that "a corporate culture lacking in trust fosters a defensive, suspicious, insular and fearful mind-set, depleting organisational energy and hampering creativity" (Mackey et al., 2014, p.221). Continuing their argument by stating that "Trust is a twoway street. In order to be trusted, we need to show trust. Leaders must trust people to use their best judgement, instead of trying to control them with too many directives and rules" (Mackey et al., 2014, p.223). Consequently, according to Mackey and Sisodia, CS integration within Whole Foods means building trust as a leaders' responsibility. A strong leader should create a working environment in which people feel trusted and where they have ownership over their decisions. This stimulates creativity and innovation. It can, therefore, be argued that the CS integration approach Mackey et al. (2014) describe fit perspective 1 and 3.

Throughout his book on the Interface approach, Ray Anderson describes how he came to realise that a drastic change was necessary and how he convinced his, sometimes sceptical, employees. He stresses the importance of good leadership stating "there is a natural limit to what any one of us can accomplish, but no limit to what leadership can do. Especially with the right followers" (Anderson, 2010, p.212). He selected the right followers himself, to fulfil his mission. It can, therefore, be argued that the CS integration approach Anderson (2010) describes fit perspective 1.

Anders Dahlvig stresses that for IKEA corporate cultural change, with regard to the integration of CS, should be strongly guided and initiated by strong leadership. This is in line with the perspective 1 approach. The main argument Dahlvig gives for this statement is that it is a complex topic, for which extensive knowledge is necessary to be able to formulate a well-founded opinion. Therefore, "many employees need clear guidance from the management before they feel comfortable about the chosen direction" (Dahlvig, 2011, p.33). Moreover, Dahlvig argues that only a strong leader can integrate a long-term perspective and determine core values and the willingness to take risks. Through his vision, the leader guides the company towards corporate cultural change, by for example only promoting managers who share the core values of the company. It can, therefore, be argued that the CS integration approach Dahlvig (2011) describes fit perspective 1 .

Jeffrey Hollender and Bill Breen of Seventh Generation are the odd ones out, in comparison to the others. They argue that a high level of ambiguity, resulting in less accountability is necessary to increase an employee's psychological safety. They do this to avoid feelings of fear on the workplace as "fear is endemic" (Hollender et al., 2010). Psychological safety is key and "fear has a way of boomeranging back on performance" (Hollender et al., 2010, p. 56-57). Enthusiasm and creativity are stimulated by less strict company expectations, resulting in innovative ideas as it allows employees to think more outside the box. It makes employees feel more responsible as they can make more decisions independently, which increases their motivation. Hollender et al. (2010) argue this, stating "an industrious workforce almost never outperforms an enthusiastic workforce" (Hollender et al., 2010, p. 57). It can, therefore, be argued that the CS integration approach Hollender et al. (2010) describe fit perspective 3 .

In sum, the book authors have different descriptions of how CS integration influences corporate cultural change. Some focus on responsibilities, where others describe how they have structured the change process. What can be derived from this analysis is a strong trend in corporate cultural change that fits the perspective 1 description of Martin (1992) emphasising the role of strong leadership in corporate cultural change. This an interesting outcome but can also be caused by a bias as most authors fulfil the role of these conscious leading change agents within the companies described.

\section{Discussion on learnings from practice and science}

The testimonies of 6 successful practitioners are being used as a source for practical grounded learning by working with and reflecting upon the practical and theoretical interests on CS integration from an organisational culture perspective, several topics for discussion arise: partly as learnings on the integration of CS and partly as learnings for CS integration researchers. While the goal of this article is to improvement of research on CS integration, the discussion is based on the latter and structured according to corporate culture, corporate values, and mechanisms that contribute to changing corporate culture. The discussion will finalise with methodological reflections.

\subsection{Corporate culture}

Where Baumgartner (2009b) and Schein (2010) emphasise a 
learning history on organisational cultural change to question a state of cognitive stability and start a process of cognitive transformation, Table 5 shows that industrial change agents mostly tend to apply the integration approach (i.e. perspective 1 ; all except for Hollender et al. (2010)), but with elements of the differentiation (i.e. perspective 2; Chouinard and Stanley (2012)) or fragmentation approach (i.e. perspective 3; Mackey et al. (2014)). While learning from organisational change through a cognitive perspective it is still a question of how organisations and their change agents can best deal with these triple alternative views. Appendix 3 shows that scholars (i.e. Marcel van Marrewijk, Tobias Hahn, Marc Epstein and Martina Linnenluecke) often tend to choose one such position, defending that way of looking and combating the alternative views, arguing that their representation of reality is the only valid or effective approach. We argue, like Martin, that such a combative attitude is not very fruitful (Martin, 1992). As can be seen in Appendix 3, industrial change agents apply mixtures of the imperatives taken from the various perspectives.

All CS scholars describe the three perspectives as being mutually exclusive, while various industrial CS change agents (i.e. Marcel van Marrewijk, Tobias Hahn, Marc Epstein and Martina Linnenluecke) implicitly define a corporate cultural change process moving from one perspective to another. Companies that did not start from a CS perspective (i.e. Herman Miller, Interface and IKEA according to consecutively Ruch (2003), Anderson (2010) and Dahlvig (2011)) stay in 'perspective 1 '. Here, the industrial change agents often face difficulties in convincing their employees of the new vision and establishing a corresponding corporate culture. However, once this infrastructure is set, corporate cultural change may also occur through a 'perspective 2' or 'perspective 3' approach as the leader turns from a conductor into a more observing role. This is something that is highly visible in the case of Patagonia (according to Chouinard and Stanley (2012)). Patagonia also start from a 'perspective 1' approach, although as the leader can from the start select people that fit the CS vision, the desired corporate culture was more easily established.

In sum, it can be concluded that this type of companies often move much faster into a consecutive perspective approaches to corporate cultural change. Here one could reason that leaders in real life intuitively apply what is best in their specific situations, emphasising a more transdisciplinary approach to identify such practical grounded learnings by working with and reflecting upon the practical and theoretical interests of society and science simultaneously (as emphasised by Breda et al. (2016)).

\subsection{Corporate values}

Changing a corporate culture towards enhanced CS performance starts with recognising the importance of the congruence between the CS values at individual and corporate levels (according to Finegan, 2000; Posner and Schmidt, 1993). Although the identification of the various CS value levels can be found in all analyses of this article, the transition between the various value levels is described differently: the scientific literature on CS (especially Baumgartner (Baumgartner, 2009b \& 2014) Azapagic (Azapagic, 2003; Azapagic and Perdan, 2005; Azapagic, 2003) and Epstein (Epstein and Widener, 2010; Epstein and Buhovac, 2010)) defines it as a rational and planned linear transition model, whereas industrial CS change agents do not (see Appendix 2 and Table 4). Industrial CS change agents (especially Ray Anderson of Interface) describe their transition often as an awakening, after which they change course drastically. This awakening leads to a change of corporate values and vision, stimulated by the change agents. It can be as radical as a company directly transitioning from the compliance phase into a holistic value level, as has been the case for
Interface. This does not mean that its practices immediately align with the new vision; a learning history on organisational cultural change ensures reaching (as mentioned by Baumgartner (2009b) and Schein (2010)) the set goal.

Finally, the scientific literature on CS only mentions the different CS value levels and does not give any guidance on how a transition from one value level to another takes place. A longitudinal research approach is needed in order to capture this transitional process.

\subsection{Changing corporate culture}

Although the three perspectives by Martin (1992) used in this article present different and on various points competing suggestions, this threefold distinction can also be found in more recent literature on framing organisational change, with a certain dominance of the perspective 1 styles (see e.g. Beer et al., 1990; Kotter, 2007), but also approaches addressing organisational change as a multi-authored negotiation (Buchanan and Dawson, 2007; Thomas et al., 2011) or as discourse (Heracleous and Barrett, 2001). In this article all three analyses describe the leader-centred approach as an important way to initiate change: all CS scholars included in the analysis (see Appendix 3) do not mention any other way to initiate corporate cultural change.

Yet another way of dealing with the theoretical diversity in perspectives is to link them to the time dimension. This implies that in the course of the lifespan of a company the perspectives may follow a certain sequence, thus applying a stage theory of change (Martin, 1992). For example, new start-ups and companies breaking through may be very much oriented around the strong personality of the founding entrepreneur, fitting an integration perspective, and later, when the firm is strongly growing and developing into diverse business units, a shift into the differentiation or a fragmentation perspective may occur. Whole Foods Market (according to Mackey et al. (2014)) reflects this, showing a mix of these approaches. However, we also see in the narratives of companies emerging from a critical environmentalist 'sub'-culture (Whole Foods Market and Seventh Generation), that from the start founders already take a non-traditional value orientation, which reflects the highest CS value levels as shown in Appendix 2 (care-, synergistic and holistically driven). This value orientation (according to Van Marrewijk and Werre, 2003; Van Marrewijk, 2004) also matches a management approach which fits well with the fragmentation perspective. In contrast to this, the other four companies are incumbents, each with their history of strategy growth from the pre-CS and compliance-driven level to these higher value levels, which in all cases starts off mostly with an integration perspectiveinspired approach. Here the core question would be what kind of event(s) urges companies to make the shift; what has been the catalyst? These four cases illustrate forms of sudden awareness caused by encounters with thought leaders (Interface), or external criticism (Ikea), as well as forms of gradual recognition of the severity of impacts by the leader (Patagonia, Herman Miller). The narratives in these books do not display whether the management style actually changed with the CS transformation of these companies, but it shows that the approach applied and promoted by these companies does most resemble the integration perspective (Herman Miller, Interface and Ikea), or with some elements of differentiation (Patagonia).

\subsection{Methodological reflections}

The classical framework of three alternative perspectives by Martin (1992) on organisations enriches the discourse on successful integration of CS into the organisational culture. Whereas in any organisation elements of all three perspectives can be discovered, 
any single perspective of the three ignores or distorts crucially important aspects of any organisation's culture. For CS integration research to capture the changes during the CS transformation of organisations the time dimension should be included emphasising the use of longitudinal research methods. Finally, we can conclude that using the narratives of industrial change agents proves to be fruitful for further elaboration of, in this research, the theory of CS integration (also concluded by Goodman et al., 2017; Willems et al., 2013).

\section{Conclusions}

We firstly conclude that CS scholars tend to focus on one of three alternative approaches suggested by organisational change scholars, for the optimisation of interventions in the social organisational dynamics, while industry leaders intuitively apply what is best in their specific situations, resulting in a mix of approaches. Consequently, the combative attitude of scholars is not very fruitful.

Secondly, by analysing both scientific and professional literature on optimising social interventions in business activities Martin's three perspectives could be seen as developmental stages of the transformation process of companies. Including this time dimension enables a longitudinal analysis to capture the kind of events urging companies to make the shift to become more sustainable. Therefore, we call for a multi-perspective research approach: improving our understanding of the social dynamics of organisations adapting their CS strategies over a longer time span of up to 10 years would move us beyond the currently dominating research based on single measurements of practices and performances. Such longitudinal transdisciplinary research approaches will lead to more valuable insights that are currently missing for both the business world and the scientific community.

\section{Appendix A. Supplementary data}

Supplementary data related to this article can be found at https://doi.org/10.1016/j.jclepro.2018.07.173.

\section{Appendix 1}

Literature used by Vermeulen and Witjes (2016) in their review of recent literature on CS integration approaches.

\section{Appendix 2}

\begin{tabular}{|c|c|c|}
\hline geography & country & authors \\
\hline \multirow[t]{7}{*}{ Europe } & $D \& F$ & $\begin{array}{l}\text { Hahn et al. (Hahn et al., 2015; Hahn and } \\
\text { Scheermesser, 2006) }\end{array}$ \\
\hline & A & $\begin{array}{l}\text { Baumgartner et al. (Baumgartner \& Ebner, } \\
\text { 2010; Baumgartner, 2009b; 2014) }\end{array}$ \\
\hline & $\mathrm{D}$ & $\begin{array}{l}\text { Schaltegger et al. (Figge et al., 2002; Schaltegger } \\
\text { et al., 2013) }\end{array}$ \\
\hline & UK \& F & $\begin{array}{l}\text { Lindgreen \& Maon et al. (Lindgreen et al., 2010; } \\
\text { Lindgreen et al., 2009; Lindgreen and Swaen, } \\
\text { 2010) }\end{array}$ \\
\hline & $\mathrm{NL}$ & $\begin{array}{l}\text { Cramer et al. (Cramer, 2005; Van Der Heijden } \\
\text { et al., 2010) }\end{array}$ \\
\hline & $\mathrm{NL}$ & $\begin{array}{l}\text { Marrewijk et al. (Marrewijk van, 2003; Marcel } \\
\text { Van Marrewijk, 2004) }\end{array}$ \\
\hline & UK & $\begin{array}{l}\text { Azapagic et al. (Azapagic, 2003, 2004; Azapagic } \\
\text { and Perdan, 2005) }\end{array}$ \\
\hline \multirow[t]{2}{*}{ North America } & Canada & $\begin{array}{l}\text { Searcy et al. (Asif et al., 2011; Ahi and Searcy, } \\
\text { 2014) }\end{array}$ \\
\hline & USA & $\begin{array}{l}\text { Epstein et al. (Epstein and Widener, 2010; } \\
\text { Epstein and Buhovac, 2010) }\end{array}$ \\
\hline Oceania & Australia & $\begin{array}{l}\text { Linnenluecke et al. (Linnenluecke and Griffiths, } \\
\text { 2010; Linnenluecke et al., 2009) }\end{array}$ \\
\hline
\end{tabular}

Results of analysis on whether most recent scientific authors in the field of CS address the different value-related drivers for the implementation of CS as identified by Van Marrewijk and Werre (2003).

\begin{tabular}{|c|c|c|c|c|c|c|}
\hline \multirow[t]{2}{*}{ Articles } & \multicolumn{6}{|c|}{ Value levels (Van Marrewijk and Werre, 2003; Van Marrewijk, 2004) } \\
\hline & $\begin{array}{l}\text { Pre-CS (2003, } \\
\text { p.112) }\end{array}$ & $\begin{array}{l}\text { Compliance driven } \\
\text { CS }(2003, \text { p. } 112)\end{array}$ & $\begin{array}{l}\text { Profit driven CS } \\
\text { (2003, p.112; 2004, } \\
\text { p.137) }\end{array}$ & $\begin{array}{l}\text { Care driven CS ( } 2003 \text {, } \\
\text { p.112) }\end{array}$ & $\begin{array}{l}\text { Synergistic } \\
\text { driven } \\
\text { CS }(2003, \\
\text { p.112; } \\
2004 \text {, p. } 137, \\
138)\end{array}$ & $\begin{array}{l}\text { Holistically driven CS } \\
\text { (2003, p. 112) }\end{array}$ \\
\hline $\begin{array}{l}\text { Cory Searcy (Searcy, 2011; } \\
\text { Ahi and Searcy, 2014; Asif et al., } \\
\text { 2013) }\end{array}$ & $(2011$, p.45) & $(2014, \mathrm{p} .120)$ & $(2014, \mathrm{p} .120)$ & $(2014, \mathrm{p} .120)$ & & $\begin{array}{l}(2014, \text { p. } 120 ; 2013, \\
\text { p.7) }\end{array}$ \\
\hline $\begin{array}{l}\text { Tobias Hahn (Hahn et al., 2015; Hahn } \\
\text { and } \\
\text { Scheermesser, 2006) }\end{array}$ & $\begin{array}{l}(2015, \mathrm{p} .4 ; 2006 \\
\text { p.152) }\end{array}$ & $\begin{array}{l}(2015, \text { p.4; 2006, } \\
\text { p.152) }\end{array}$ & $\begin{array}{l}(2015, \text { p. } 4 ; 2006 \\
\text { p. } 152,158)\end{array}$ & $(2006$, p.150, 152) & & $\begin{array}{l}(2015, \text { p. } 5 ; 2006, \text { p. } \\
159)\end{array}$ \\
\hline $\begin{array}{l}\text { Rupert Baumgartner (Baumgartner, } \\
\text { 2009b; 2014) }\end{array}$ & $\begin{array}{l}(2014, \text { p. } 264 \\
\text { 2009, p.110) }\end{array}$ & $\begin{array}{l}(2014, \text { p.264; } 2009, \\
\text { p.110) }\end{array}$ & $\begin{array}{l}(2014, \text { p. } 258,260 \\
264)\end{array}$ & $(2014$, p.260) & $\begin{array}{l}(2014, \text { p.260; } \\
\text { 2009, p.110) }\end{array}$ & $\begin{array}{l}\text { (2014, p.264; 2009, } \\
\text { p. 111) }\end{array}$ \\
\hline $\begin{array}{l}\text { Stefan Schaltegger (Schaltegger et al., } \\
\text { 2013) }\end{array}$ & & & (2013, p.219) & (2013, p. 219) & $(2013, \mathrm{p} .220)$ & $(2013$, p. 219,220$)$ \\
\hline $\begin{array}{l}\text { Adisa Azapagic (Azapagic, 2003; } \\
\text { Azapagic } \\
\text { and Perdan, 2005; Azapagic, 2003) }\end{array}$ & $(2003$, p.303) & $\begin{array}{l}(2003, \text { p.308; 2004, } \\
\text { p.651) }\end{array}$ & $\begin{array}{l}(2003, \text { p. } \\
\text { 303,304,308; } \\
\text { 2004, p.640) }\end{array}$ & $\begin{array}{l}\text { (2003, p.308; 2004, p. } \\
641)\end{array}$ & $\begin{array}{l}(2003, p .303 \\
312)\end{array}$ & $\begin{array}{l}(2003, \text { p. } 304,308 ; \\
2004, \\
\text { p. } 643)\end{array}$ \\
\hline $\begin{array}{l}\text { Marc Epstein (Epstein and Widener, } \\
\text { 2010; } \\
\text { Epstein and Buhovac, 2010) }\end{array}$ & $(2010$, p.306, 308) & $(2010$, p.306, 308) & $\begin{array}{l}(2010, \text { p.306, 308, } \\
311 ; \\
\text { 2001, p.589, 591, 592, } \\
598)\end{array}$ & $\begin{array}{l}\text { (2010, p.306; 2001, p. } \\
595)\end{array}$ & $(2001, \mathrm{p} .586)$ & $(2010$, p. 312) \\
\hline $\begin{array}{l}\text { Jacqueline Cramer (Cramer, 2005; Van } \\
\text { der } \\
\text { Heijden et al., 2010) }\end{array}$ & & & (2005, p.587) & $(2005$, p.587, 591) & $\begin{array}{l}(2005, \mathrm{p} .583 \\
587)\end{array}$ & $(2005$, p.587) \\
\hline $\begin{array}{l}\text { Martina Linnenluecke (Linnenluecke } \\
\text { and }\end{array}$ & & $\begin{array}{l}(2010, \text { p.360; } 2009, \\
\text { p.436) }\end{array}$ & $(2010$, p.360) & & $(2010$, p.362) & \\
\hline
\end{tabular}


(continued)

Articles

Value levels (Van Marrewijk and Werre, 2003; Van Marrewijk, 2004)

Pre-CS (2003, Compliance driven Profit driven CS Care driven CS (2003, Synergistic Holistically driven CS

p.112) CS $(2003, \mathrm{p} .112)-(2003, \mathrm{p} .112 \cdot 2004,0.112)$

p.137)

driven

(2003, p. 112)

CS $(2003$

p.112;

2004, p. 137 ,

138)

Griffiths, 2010; Linnenluecke et al.,

2009)

Dexter Dunphy (Dunphy et al., 2006)

Rodrigo Lozano (Lozano, 2008; 2013)

(2006, p.37)

(2006, p.69) (2006, p.37)

(2013, p.277) (2008, p. 500)

(2006, p.37)

(2008, p. 506; 2013, p. 276)

\section{Appendix 3}

Corporate cultural change mechanisms as described by scientific CS literature, classified by using the different scientific perspectives as identified by Meyerson and Martin (1987). Page numbers of where the main reasoning can be found in the book are shown for transparency.

\begin{tabular}{|c|c|c|c|}
\hline \multirow[t]{2}{*}{ Articles } & \multicolumn{3}{|l|}{ Martin (1992) } \\
\hline & $\begin{array}{l}\text { 'Perspective 1' Integration: } \\
\text { harmony and homogeneity }\end{array}$ & $\begin{array}{l}\text { 'Perspective 2' Differentiation: } \\
\text { separation and conflict }\end{array}$ & $\begin{array}{l}\text { 'Perspective } 3 \text { ' Fragmentation: } \\
\text { multiplicity and flux }\end{array}$ \\
\hline $\begin{array}{l}\text { Marcel van Marrewijk (Van Marrewijk and Werre, 2003; } \\
\text { Van Marrewijk, 2004) }\end{array}$ & $(2004$, p.139) & $(2004$, p.138-139) & $(2003$, p.108-109) \\
\hline \multicolumn{4}{|l|}{ Cory Searcy (Searcy, 2011; Ahi and Searcy, 2014) } \\
\hline Muhammad Asif (Asif et al., 2013) & $(2013, \mathrm{p} .10)$ & & $(2013$, p.11) \\
\hline $\begin{array}{l}\text { Tobias Hahn (Hahn et al., 2015; Hahn and Scheermesser, } \\
\text { 2006) }\end{array}$ & (2006, p.152; 2015, p. 8) & (2006, p.152; 2015, p.13) & (2015, p. 22) \\
\hline Rupert Baumgartner (Baumgartner, 2009b; 2014) & (2009, p.107; 2014, p.267) & $(2014$, p.267) & \\
\hline \multicolumn{4}{|l|}{ Stefan Schaltegger (Schaltegger et al., 2013) } \\
\hline $\begin{array}{l}\text { Adisa Azapagic (Azapagic, 2003; Azapagic and Perdan, } \\
\text { 2005; Azapagic, 2003) }\end{array}$ & $(2005$, p.112; 2003, p.305) & $(2005$, p.112) & \\
\hline $\begin{array}{l}\text { Marc Epstein (Epstein and Widener, 2010; Epstein and } \\
\text { Buhovac, 2010) }\end{array}$ & $(2010$, p.307) & $(2001$, p.587) & $(2010$, p. 308) \\
\hline $\begin{array}{l}\text { Jacqueline Cramer (Cramer, 2005; Van der Heijden et al., } \\
\text { 2010) }\end{array}$ & (2005, p.583; 2010, p.1787) & & $(2010$, p.1789) \\
\hline $\begin{array}{l}\text { Martina Linnenluecke (Linnenluecke and Griffiths, 2010; } \\
\text { Linnenluecke et al., 2009) }\end{array}$ & $(2010$, p.359) & $(2010$, p.363) & (2010; p.359 \\
\hline Dexter Dunphy (Dunphy et al., 2006) & $(2006, \mathrm{p} .136)$ & $(2006$, p.305) & \\
\hline Rodrigo Lozano (Lozano, 2008; 2013) & $(2013$, p.281) & (2013, p. 278 & \\
\hline
\end{tabular}

\section{References}

Ahi, P., Searcy, C., 2014. An analysis of metrics used to measure performance in green and sustainable supply chains. J. Clean. Prod.

Allaire, Y., Firsirotu, M.E., 1984. Theories of organizational culture. Organ. Stud. https://doi.org/10.1177/017084068400500301.

Anderson, R., 2010. Confessions of a Radical Industrialist: How Interface Proved that You Can Build a Successful Business without Destroying the Planet. Random House. Retrieved from: https://books.google.de/books?id=eEQx8DS1gEsC.

Asif, M., Searcy, C., Zutshi, A., Ahmad, N., 2011. An integrated management systems approach to corporate sustainability. Eur. Bus. Rev. 23 (4), 353-367.

Asif, M., Searcy, C., Zutshi, A., Fisscher, O.A.M., 2013. An integrated management systems approach to corporate social responsibility. J. Clean. Prod. 56, 7-17. https://doi.org/10.1016/j.jclepro.2011.10.034.

Azapagic, A., 2003. Systems approach to corporate sustainability: a general management framework. Process Saf. Environ. Protect. 81 (5), 303-316. https://doi. org/https://doi.org/10.1205/095758203770224342.

Azapagic, A., 2004. Developing a framework for sustainable development indicators for the mining and minerals industry. J. Clean. Prod. 12 (6), 639-662.

Azapagic, A., Perdan, S., 2005. An integrated sustainability decision-support framework Part I: problem structuring. Int. J. Sustain. Dev. World Ecol. 12 (2) 98-111. https://doi.org/10.1080/13504500509469622.

Baumgartner, R.J., 2009a. Organizational culture and leadership_ preconditions for the development of a sustainable corporation - Baumgartner - 2009 - sustainable development - Wiley online Library.pdf. Sustain. Dev. https://doi.org/ $10.1002 / \mathrm{sd}$.

Baumgartner, R.J., 2009b. Organizational culture and leadership: preconditions for the development of sustainable corporation. Sustain. Dev. 17 (2), 102-113. https://doi.org/10.1002/sd.405.

Baumgartner, R.J., 2014. Managing corporate sustainability and CSR: a conceptual framework combining values, strategies and instruments contributing to sustainable development. Corp. Soc. Responsib. Environ. Manag. 21 (5), 258-271. https://doi.org/10.1002/csr.1336.

Baumgartner, R.J., Ebner, D., 2010. Corporate sustainability strategies: sustainability profiles and maturity levels. Sustain. Dev. 89 (February), 76-89.

Beer, M., Eisenstat, R.A., Spector, B., 1990. Why change programs Don't produce change. Harv. Bus. Rev. 68 (6), 158.

Bedford, D.S., 2015. Management control systems across different modes of innovation: implications for firm performance. Manag. Account. Res. 28, 12-30. https://doi.org/10.1016/j.mar.2015.04.003.

Breda, John, V., Musango, J., Brent, A., 2016. Undertaking individual transdisciplinary $\mathrm{PhD}$ research for sustainable development. Int. J. Sustain. High Educ. 17 (2), 150-166. https://doi.org/10.1108/IJSHE-07-2014-0107.

Broom, L., Selznick, P., 1963. Sociology. A Text with Adapted Readings, Leonard Broom, Philip Selznick. Harper, New York.

Brunsson, N., 1982. The irrationality of action and action rationality: decisions, ideologies and organizational actions. J. Manag. Stud. 19 (1), 29-44. https://doi. $\operatorname{org} / 10.1111 / \mathrm{j} .1467-6486.1982 . t b 00058 . x$.

Buchanan, D., Dawson, P., 2007. Discourse and audience: organizational change as multi-story process. J. Manag. Stud. 44 (5), 669-686. https://doi.org/10.1111/j. 1467-6486.2006.00669.x.

Burgers, J.H., Jansen, J.J.P., Van den Bosch, F.A.J., Volberda, H.W., 2009. Structura differentiation and corporate venturing: the moderating role of formal and informal integration mechanisms. J. Bus. Ventur. 24 (3), 206-220. https:// doi.org/10.1016/j.jbusvent.2009.01.006.

Cannon, T., 1994. Corporate Responsibility. A Textbook on Business Ethics, Governance, Environment: Roles and Responsibilities. Pitman publishing, London. 
Chouinard, Y., Stanley, V., 2012. The Responsible Company. Patagonia Inc.

Chouinard, Y., Ellison, J., Ridgeway, R., 2011. The big idea: the sustainable economy. Harv. Bus. Rev. https://doi.org/10.1111/j.1365-2214.2011.01330.x.

Chuang, Y.-T., Church, R., Zikic, J., 2004. Organizational culture, group diversity and intra-group conflict. Team Perform. Manag.: Int. J. 10 (1/2), 26-34. https://doi. org/10.1108/13527590410527568.

Clark, B.R., 1972. The organizational saga in higher education. Adm. Sci. Q. 17 (2), 178-184. https://doi.org/10.2307/2393952.

Cramer, J., 2005. Company learning about corporate social responsibility. Bus. Strat. Environ. 14 (4), 255-266. https://doi.org/10.1002/bse.432.

Dahlvig, A., 2011. The IKEA Edge: Building Global Growth and Social Good at the World's Most Iconic Home Store. McGraw-Hill Education. Retrieved from: https://books.google.de/books?id=uEgz-YsazUC.

Doppelt, B., 2003. Leading Change toward Sustainability: a Change-management Guide for Business, Government and Civil Society. Government and Civil Society. Greenleaf Publishing, Sheffield, UK. Retrieved from: http://books.google.

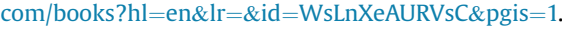

Dose, J.J., 1997. Work values: an integrative framework and illustrative application to organizational socialization. J. Occup. Organ. Psychol. 70 (3), 219-240. https://doi.org/10.1111/j.2044-8325.1997.tb00645.x.

Dunphy, D., Griffiths, A., Benn, S., 2006. Organizational Change for Corporate Sustainability: a guide for leaders and change agents of the future. In: Burnes, B. (Ed.), Organizational Change for Corporate Sustainability, second ed. Routledge, New York City.

Eisenberg, E.M., 1984. Ambiguity as strategy in organizational communication. Commun. Monogr. 51 (3), 227-242. https://doi.org/10.1080/ 03637758409390197.

Elkington, J., 2002. Corporate strategy in the chrysalis economy. Corp. Environ. Strat. 9 (1), 5-12. https://doi.org/10.1016/S1066-7938(01)00152-X.

Epstein, M.J., Buhovac, A.R., 2010. Solving the sustainability implementation challenge. Organ. Dynam. 39 (4), 306-315. https://doi.org/10.1016/j.orgdyn.2010.07. 003.

Epstein, M.J., Widener, S.K., 2010. Identification and use of sustainability performance measures in decision-making. J. Corp. Citizen. 2010 (40), 42-73. https:// doi.org/10.9774/GLEAF.4700.2010.wi.00006.

European Commission, 2015. People Have the Power. Consumers \& Energy Effcient Products, Brussels, Belgium. https://doi.org/978-92-9202-162-7.

Finegan, J.E., 2000. The impact of person and organizational values on organizational commitment. J. Occup. Organ. Psychol. 73 (2), 149-169. https://doi.org/ 10.1348/096317900166958.

Freeman, S.J., Cameron, K.S., 1993. Organizational downsizing: a convergence and reorientation framework. Organ. Sci. 4 (1), 10-29. https://doi.org/10.1287/orsc. 4.1.10.

Friedrich, E., Wüstenhagen, R., 2017. Leading organizations through the stages of grief. Bus. Soc. 56 (2), 186-213. https://doi.org/10.1177/0007650315576151.

Glaser, B.G., Strauss, A.L., 2008. The Discovery of Grounded Theory; Strategies for Qualitative Research. N. B. AldlineTransaction, USA.

Goodman, J., Korsunova, A., Halme, M., 2017. Our collaborative future: activities and roles of stakeholders in sustainability-oriented innovation. Bus. Strat. Environ. https://doi.org/10.1002/bse.1941.

Hahn, T., Figge, F., Aragón-Correa, J.A., Sharma, S., 2017. Advancing research on corporate sustainability. Bus. Soc. 56 (2), 155-185. https://doi.org/10.1177/ 0007650315576152.

Hahn, T., Pinkse, J., Preuss, L., Figge, F., 2015. Tensions in corporate sustainability: towards an integrative framework. J. Bus. Ethics 127 (2), 297-316. https://doi, org/10.1007/s10551-014-2047-5.

Hahn, T., Scheermesser, M., 2006. Approaches to corporate sustainability among German companies. Corp. Soc. Responsib. Environ. Manag. https://doi.org/10. 1002/csr.100.

Hart, S.L., 1997. Beyond greening: strategies for a sustainable world. Harv. Bus. Rev. 75, 66-76. Retrieved from: http://search.ebscohost.com/login.aspx? direct $=$ true $\& d b=b$ th $\& A N=9706130739 \&$ site $=$ ehost-live $\&$ scope $=$ site

Heracleous, L., Barrett, M., 2001. Organizational change as discourse: communicative actions and deep structures in the context of information technology implementation. Acad. Manag. J. 44 (4), 755-778. https://doi.org/10.2307/ 3069414.

Hofstede, G., Noorderhaven, N.G., Thurik, A.R., Uhlaner, L.M., Wennekers, A.R.M., Wildeman, R.E., 2004. Culture's role in entrepreneurship: self-employment out of dissatisfaction. In: Innovation, Entrepreneurship and Culture, pp. 162-203.

Hollender, J., Breen, B., Senge, P., 2010. The Responsibility Revolution: How the Next Generation of Businesses Will Win. Wiley. Retrieved from: https://books. google.de/books?id=SMqF2zTuKjcC.

Homans, G., 1958. Social behavior as exchange. Am. J. Sociol. 63 (6), 597-606. https://doi.org/10.1086/222355.

Jarnagin, C., Slocum, J.W., 2007. Creating corporate cultures through mythopoetic leadership. Organ. Dynam. 36 (3), 288-302. https://doi.org/10.1016/j.orgdyn. 2007.04.004.

Johnson, G., 1992. Managing strategic change-strategy, culture and action. Long. Range Plan. 25 (1), 28-36. https://doi.org/10.1016/0024-6301(92)90307-N.

Jönsson, S.A., Lundin, R.A., 1976. Myths and Wishful Thinking as Management Tools. Internat. Inst. für Management u. Verwaltung. Retrieved from: https://books. google.de/books?id=3grxHAAACAAJ.

Keesing, R.M., 1981. Cultural Anthropology: A Contemporary Perspective. Harcourt Brace College Publishers.

Kleinedler, S., 2005. The American Heritage Science Dictionary. The American
Heritage Science Dictionary.

Kotter, J.P., 2007. Leading change. Why transformation efforts fail. Har. Bus. Rev. 85 (1), 96-103. https://doi.org/10.1007/s13398-014-0173-7.2.

Kotter, J.P., Heskett, J.L., 1992. Corporate culture and performance. Adm. Sci. Q. 47. https://doi.org/10.1080/15367100903202706.

Lindgreen, A., Córdoba, J.-R., Maon, F., Mendoza, J.M., 2010. Corporate social responsibility in Colombia: making sense of social strategies. J. Bus. Ethics 91 (S2), 229-242.

Lindgreen, A., Swaen, V.V., Johnston, W.J., 2009. Corporate social responsibility: An empirical investigation of U.S. organizations. J. Bus. Ethics, 85 (Suppl. 2) $303-323$.

Lindgreen, A., Swaen, V., 2010. Corporate social responsibility. Int. J. Manag. Rev. 12 (1), 1-7.

Linnenluecke, M.K., Griffiths, A., 2010. Corporate sustainability and organizational culture. J. World Bus. 45 (4), 357-366. https://doi.org/10.1016/j.jwb.2009.08 006.

Lozano, R., 2008. Developing collaborative and sustainable organisations. J. Clean. Prod. 16 (4), 499-509.

Lozano, R., 2013. Are companies planning their organisational changes for corporate sustainability? an analysis of three case studies on resistance to change and their strategies to overcome it. Corp. Soc. Responsib. Environ. Manag. 20 (5) 275-295.

Linnenluecke, M.K., Russell, S.V., Griffiths, A., 2009. Subcultures and sustainability practices: the impact on understanding corporate sustainability. Bus. Strat. Environ. 18 (7), 432-452.

Mackey, J., Sisodia, R., George, B., 2014. Conscious Capitalism, with a New Preface by the Authors: Liberating the Heroic Spirit of Business. Harvard Business Review Press. Retrieved from: https://books.google.de/books?id=KZvBAgAAQBAJ.

Marrewijk van, M., 2003. Concepts and definitions of CSR and corporate sustainability: between agency and communion. J. Bus. Ethics 44 (May), 95-105.

Martin, J., 1992. Cultures in Organizations: Three Perspectives. Oxford University Press, New York.

Martin, J., Siehl, C., 1983. Organizational culture and counterculture: an uneasy symbiosis. Organ. Dynam. 12 (2), 52-64. https://doi.org/10.1016/0090-2616(83) 90033-5.

Meyerson, D., Martin, J., 1987. Cultural change: an integration of three different views [1]. J. Manag. Stud. 24 (6), 623-647. https://doi.org/10.1111/j.1467-6486. 1987.tb00466.x.

Mohr, L.B., 1983. The Implications of Effectiveness Theory for Managerial Practice in the Public Sector. Organizational Effectiveness: A Comparison of Multiple Models.

Morris, R.T., 1956. A typology of norms. Am. Socio. Rev. 21 (5), 610-613. https://doi org/10.2307/2089098.

Pettigrew, A.M., 1985. The Awakening Giant: Continuity and Change in ICI. Basil Blackwell Publishers, Oxford, UK.

Posner, B.Z., Schmidt, W.H., 1993. Values congruence and differences between the interplay of personal and organizational value systems. J. Bus. Ethics 12 (5), 341-347. https://doi.org/10.1007/BF00882023.

Quinn, R., Cameron, K., 2006. Diagnosing and changing organizational culture Training 43. https://doi.org/10.1111/j.1744-6570.2006.00052_5.x.

Rokeach, M., 1973. The Nature of Human Values, vol. 70. New York Free Press. https://doi.org/10.2307/1959882.

Ruch, D., 2003. Leaders and Followers: Lessons from 45 Years at Herman Miller, Inc Trafford Publishing. Retrieved from: https://books.google.de/books? id=zxEWE64eZkIC.

Schall, M.S., 1983. A communication-rules approach to organizational culture. Adm. Sci. Q. 28 (4), 557-581. https://doi.org/https://doi.org/10.2307/2393009.

Schaltegger, S., Beckmann, M., Hansen, E.G., 2013. Corporate sustainability meets transdisciplinarity. Bus. Strat. Environ. 22 (4), 217-218.

Schein, E.H., 1990. Organizational culture. Am. Psychol. 45 (2), 109-119. https://doi org/10.1037//0003-066X.45.2.109.

Schein, E.H., 2010. Organizational Culture and Leadership. Vasa, 4rd ed. Jossey-Bass, San Francisco, USA. Retrieved from: http://medcontent.metapress.com/index/ A65RM03P4874243N.pdf.

Searcy, C., 2011. Updating corporat me sustainability performance measurement systems. Meas. Bus. Excell. 15 (2), 44-56.

Siebenhüner, B., Arnold, M., 2007. Organizational learning to manage sustainable development. Bus. Strat. Environ. 16 (5), 339-353. https://doi.org/10.1002/bse. 579.

Slawinski, N., Pinkse, J., Busch, T., Banerjee, S.B., 2017. The role of short-termism and uncertainty avoidance in organizational inaction on climate change. Bus. Soc. 56 (2), 253-282. https://doi.org/10.1177/0007650315576136.

Thomas, R., Sargent, L.D., Hardy, C., 2011. Managing organizational change: negotiating meaning and power-resistance relations. Organ. Sci. 22 (1), 22-41 https://doi.org/10.1287/orsc.1090.0520.

Trice, H.M., Beyer, J.M., 1984. Studying organizational cultures through rites and ceremonials. Acad. Manag. Rev. 9 (4), 653-669. https://doi.org/10.5465/AMR. 1984.4277391.

Van Der Heijden, A., Driessen, P.P.J., Cramer, J.M., 2010. Making sense of corporate social responsibility: exploring organizational processes and strategies. J. Clean. Prod. 18 (18), 1787-1796. https://doi.org/10.1016/j.jclepro.2010.07.024.

Van Maanen, J., Barley, S.R., 1984. Occupational communities: culture and control in organizations. Res. Organ. Behav. 287-365. https://doi.org/10.1108 02621710810871790

Van Marrewijk, M., Werre, M., 2003. Multiple levels of corporate sustainability. 
J. Bus. Ethics 44 (2), 107-119. https://doi.org/10.1023/A:1023383229086.

Van Marrewijk, M., 2004. The social dimension of organizations: recent experiences with great place to work?? assessment practices. J. Bus. Ethics. https://doi.org/ 10.1007/s10551-004-1897-7.

Vermeulen, W.J.V., Witjes, S., 2016. On addressing the dual and embedded nature of business and the route towards corporate sustainability. J. Clean. Prod. 112,
2822-2832. https://doi.org/10.1016/j.jclepro.2015.09.132.

Waterman, R.H., Peters, T. 1983. In Search of Excellence. Lessons from America's Best-run Companies. https://doi.org/10.1111/j.1467-6486.1994.tb00634.x.

Willems, J., Ru, M.C., Stehfest, E., 2013. Sustain. Sci. 110. https://doi.org/10.1073/ pnas.1206191109. 